\title{
O POVO NA HISTÓRIA DE UM POVO: A VIDA DO NEGRO NO BRASIL ENTRE OS SÉCULOS XVI E XXI
}

\section{ARTIGO ORIGINAL}

JÚNIOR, João Santos da Silva ${ }^{1}$

FELIX, José Carlos ${ }^{2}$

JÚNIOR, João Santos da Silva. FELIX, José Carlos. O povo na história de um povo: A vida do negro no Brasil entre os séculos XVI e XXI. Revista Científica Multidisciplinar Núcleo do Conhecimento. Ano 05, Ed. 03, Vol. 07, pp. 137-163. Março de 2020. ISSN: 2448-0959, Link de acesso: https://www.nucleodoconhecimento.com.br/educacao/povo-na-historia

\section{RESUMO}

O presente trabalho traz em sua estrutura um caráter bibliográfico, constituído como estudo de relevância social. Autores como Munanga (2006), Gomes (2006), Dantas Mattos; Abreu (2012), entre outros, embasam e corroboram com as ideias discorridas ao longo dos textos. $O$ trabalho aborda a vida do negro na sociedade desde a diáspora, as relações antes e depois da Lei Áurea (1888), as ações afirmativas, o sistema educacional com a lei 10.639, além do (re) conhecimento de comunidades remanescentes quilombola. Os textos buscam discorrer de forma sucinta e completa como ocorreram todos os processos até os dias de hoje, lutas e movimentos pelo reconhecimento do negro na sociedade, identificando fatores com descriminação e

1 Mestrando especial em Educação e Diversidade. Especialista em Língua Portuguesa, Matemática e Docência no Ensino Superior. Graduado em Pedagogia. Licenciando em Matemática.

2 Doutorado em Teoria e História Literária. Mestrado em Inglês: Estudos Linguísticos e Literários. Especialização em Língua Inglesa - Ensino e Secretariado Bilíngue. Graduação em Letras. 
racismo, como castradores de direitos sociais e da preservação cultural da sociedade afro-brasileira. A discussão da implementação das leis que tendem a efetivação do ensino e da valorização da história e cultura afro-brasileira e africana no ambiente escolar, quais desafios à escola enfrenta quanto a prática das diretrizes curriculares nos ambientes escolares.

Palavra-chave: Diáspora, Lei 10.639, comunidades quilombolas.

\section{INTRODUÇÃO}

O presente trabalho busca descrever e avaliar os diferentes fatores que ao longo de séculos que tornou invisível o negro dentro da sociedade, arraigando a ideia de dependência e o subjugando como ser inferior. As diferentes lutas e movimentos tendem pela ruptura dessas visões e a busca pela igualdade de direitos entre todo cidadão independentemente de cor, raça, religião, ou outras características que determinam diferentes grupos sociais.

Quando falamos do "negro na diáspora" buscamos trazer a luz dos leitores diversos caminhos pelos quais o negro foi trazido de forma forçada para o Brasil, por qual motivo eles foram arrancados de sua terra, para viver em um continente totalmente estranho e vivendo sob a forma de trabalhos forçados para enriquecer uma parcela de senhores privilegiados? O segundo tópico trata do "negro antes de 1888" definem quais dificuldades os mesmos enfrentavam, para sobreviver. Após a chegada ao Brasil os negros eram comercializados e levados ao trabalho forçado sobe tortura nas fazendas de açúcar principalmente na região nordeste, logo no início da escravidão no Brasil. Os escravizados depois de um período passaram a ser usados em outras atividades como mineração.

O terceiro tópico trata-se da "vida após a abolição" que revela as dificuldades enfrentadas pelos ex-escravos após a assinatura da lei áurea, problemas como: racismo, preconceito, falta de moradias, que, entre outros fatores, fizeram com que a população negra sempre dependesse da vontade do branco. Embora a liberdade existisse no papel, na sociedade tornava-se cada vez mais difícil a convivência 
passiva, e a desigualdade aumentava entre o negro e o branco. O quarto tópico trata de: "as revoltas e os movimentos", que foram fatores importantes na luta pelo respeito e reconhecimento do negro na sociedade e aquisição de direitos que the eram negados. O quinto tópico trata da: "Da teoria à Prática" que discorre sobre a criação e implementação da lei 10.639 que foi criada no ano de 2003 que não é colocada em prática na sua totalidade dificultando assim o respeito e reconhecimento da história e cultura negra. A lei discorre sobre o ensino de História e Cultura Afro-brasileira e Africana nas escolas de educação básica que compreende desde o ensino fundamental até o médio. O sexto tópico é "comunidades remanescentes de quilombo e o processo educacional" dentro desse tema trabalha-se as leis que legitimam a criação e o reconhecimento de comunidades quilombolas distribuídos no Brasil, e a sua importância na preservação cultural do negro além de dialogar com o processo educacional dentro da comunidade valorizando os saberes dos ancestrais e auto afirmação como pertencentes a um grupo étnico de história e lutas. "Comunidade Quilombola de Raposa" trata-se de um trabalho de campo realizando visando conhecer uma comunidade de remanescentes para legitimar os dados aqui presentados durante todo $\mathrm{o}$ trabalho. $\mathrm{O}$ trabalho conta com a metodologia que foi resultada de estudos principalmente bibliográficos, e os resultados e discussões que tratam do trabalho como um processo complexo e prazeroso.

\section{O NEGRO DA DIÁSPORA}

O Brasil assim como outras regiões do mundo e da América Latina tem em sua história a marca da escravidão, algo indissociável da memória de um povo. Durante parte dos mais de 300 anos de escravidão no Brasil o tráfico Atlântico foi meio pelo qual a chamada Diáspora Africana aconteceu, embora essa debandada não tenha acontecido de forma legitima ou consensual das duas partes, esse processo fez de vários territórios inabitados, e com vastas riquezas lugares desenvolvidos socialmente e economicamente. Segundo Souza (2012) entre os séculos XVI e meados do século XIX mais de 11 milhões de escravos entre homens, mulheres e crianças foram transportados em porões de navios negreiros para o continente americano, destinos que muitos dessas pessoas ficavam pelo meio do caminho, pois seus corpos eram 
jogados ao mar, pois morriam acometidos de doenças e maus-tratos. Os que conseguiam chegar à terra firme estavam condenados à servidão.

O Brasil era uma terra rica principalmente na área da agricultura com a produção da cana de açúcar que na época foi um dos destinos mais usados pelos traficantes de escravos, estima-se que o território brasileiro recebeu cerca de quatro milhões de escravos, esse é um dos maiores fatores responsáveis atualmente pela grande população negra aqui existente. O exemplo de Salvador que se estima ser a cidade brasileira com o maior número de pretos e pardos fora do continente africano. Voltando ao termo diáspora vamos entender um pouco do seu significado. Segundo Munanga e Gomes (2006) a palavra diáspora significa dispersão que é entendido como o deslocamento, normalmente forçado ou incentivado, de grandes massas populacionais originárias de uma zona determinada para várias áreas diferentes. A partir desse conhecimento precisamos responder a seguinte pergunta: qual o motivo para que os negros africanos deixassem seu país de origem e sua família para se deslocar para outro continente? O primeiro ponto deve substituir o termo "se deslocar" pelo termo "deslocado".

Os negros não saíam de seus territórios de forma espontânea, mas sim, eram obrigados a deixar a sua terra natal e toda a vida construída no lugar em que viviam. Levados através da força a embarcarem em porões de navios e viver uma vida de servidão em um novo lugar. Mas como esses negros passavam a ser cativos e viverem uma vida de escravidão? Por que a escravização do negro no Brasil?

A pós a esquadra de Cabral aportar nas terras brasileiras, um novo mundo passou a surgir diante da possibilidade de novas riquezas. A exploração do continente foi intensificada com a mão de obra nativa que para Mattos (2012) logo foi substituída pelo escravo africano. Por que os portugueses substituíram a mão de obra nativa pela a africana? Segundo Dantas, Mattos e Abreu (2012), um dos fatores principais da substituição foi à falta de controle da coroa portuguesa para com os mesmos, o que culminou com o início do Tráfico Atlântico por volta do ano 1550. 
A utilização da força escrava tinha por objetivo a colonização e desenvolvimento do novo território, gerando lucro para a coroa portuguesa. A base para a o desenvolvimento era a produção de matéria prima como; o algodão, o tabaco e principalmente o açúcar.

As produções abasteciam principalmente o comércio europeu e enriquecia a coroa portuguesa e seus aliados, para Mattos (2012) a utilização do trabalho escravo enquadrava-se em um "sistema mercantilista", que também possibilitava o acumulo de riquezas pelas metrópoles que realizavam esse tipo de comércio, onde a matéria prima era o escravo-africano. Devemos nos situar quando surgiu a escravidão. Segundo Souza (2012) antes do século XVI já havia escravidão no continente africano, antes mesmo da chegada dos europeus, segundo a autora as guerras entre as tribos africanas na busca por conquistar novos territórios, produziam prisioneiros para as tribos dos vencedores, esses prisioneiros eram forçados a ser cativos, trabalhando na agricultura ou em trabalhos domésticos.

Ao longo do tempo a percepção da necessidade da força de trabalho do escravo para as aldeias vencedoras, despertou o interesse pela prática de comercialização de africanos escravizados o que facilitou aos europeus, valendo-se das estruturas escravocratas para o desenvolvimento e manutenção de suas colônias. Essa espécie de comercio era facilitada pelos próprios africanos que acabavam por capturar e aprisionar negros de outras tribos para vender para os comerciantes de escravo. Embora os negros lutassem por sua liberdade como diz Souza (2012) com "ataques com arco e flechas as caravelas estrangeiras" (pág. 58), muitos deles foram arrancados de sua terra para serem explorados em outros continentes.

\section{O NEGRO ANTES DE 1888}

O tráfico de negros para o Brasil era "justificado" pela necessidade que a coroa portuguesa tinha em manter a exploração do novo continente. Após a exploração do pau Brasil, o açúcar passou a ser uma das grandes fontes de riqueza e desenvolvimento da colônia no final do século XVI. Os negros que chegavam ao Brasil eram vendidos aos grandes fazendeiros e senhores de engenho, onde eram utilizados 
principalmente nas grandes plantações de cana de açúcar. As capitanias da Bahia e de Pernambuco no final do século XVI foram os que mais receberam a mão de obra escrava, por possuir na época as maiores plantações e condições geográficas para o desenvolvimento da colônia.

Segundo Mattos (2012) a grande parte do trabalho na produção açucareira eram realizadas em canaviais o que necessitava da força e mão de obra escrava, onde as jornadas de trabalho ultrapassavam às 15 horas diárias, para Gennari apud Souza (2012) os escravos tinham apenas cinco dias de descanso durante o ano. Os trabalhos eram vigiados por feitores que determinavam o ritmo de todos e caso algum dos escravos tentassem de alguma forma se rebelar, era castigado para servir de exemplo para os demais para Souza (2012 parte dos escravos que não eram mandados para as fazendas ficavam no caís, onde eram vendidos como escravos de ganhos. Os mesmos eram submetidos às atividades urbanas e o dinheiro que conseguiam era repassado aos seus senhores, ainda segundo a autora esse tipo de escravo teve grande importância na formação e consolidação dos centros urbanos.

As escravas mulheres eram forçadas a servir aos seus senhores como parceiras sexuais ou amas de leites para os filhos (crianças) dos brancos e executar o trabalho doméstico. A autora define ainda que, as que não estavam nesses serviços eram obrigadas a prostituir-se ou ao comércio de rua.

Desde a chegada dos africanos ao Brasil eles lutavam pôr a sua própria liberdade, segundo Albuquerque e Fraga Filho (2006) em toda a América ouve levantes e rebeliões de escravos, principalmente no Brasil, dentre os modelos de resistência estavam às fugas individuais ou coletivas, a desobediência, a morosidade no serviço as sabotagens nas produções, o suicídio, o banzo, o aborto (a partir de relações entre escravas e senhores donos de escravo), os assassinatos de feitores e senhores donos de escravo, o culto ao candomblé, a capoeira, danças e culturas e a formação de quilombos, no entanto os senhores donos de escravos que viam seus cativos se rebelarem ou fugir organizavam diferentes formas de castigar os mesmos, segundo Gennari (2008) os escravos capturados eram submetidos até 100 açoites na presença de todos. 
A vontade de se tornar livre era maior que a tortura sofrida, as fugas passaram a ter maior intensidade e a formação de quilombos passou acrescer no Brasil. Mas o que é quilombo?

Quilombo foi a maior forma de resistência escrava no Brasil, era o local para onde os negros que fugiam das fazendas se deslocavam, por muito tempo quilombo foi viso como um esconderijo mais para Gennari (2008) quilombo no Brasil tornou-se sinônimo de refúgio e resistência um lugar de difícil acesso e estratégico, caso viessem a sofrer algum ataque militar ou de "capitães do mato"[3]. Os escravos que conseguiam chegar ao quilombo ali se fixavam, passavam a trabalhar e produzir seu próprio alimento. Segundo Gomes (2011) o maior quilombo e mais conhecido foi o "quilombo dos palmares", que foi construído na serra da Barriga no estado de Alagoas por volta de 1597.

O quilombo recebeu esse nome por situar-se em uma região com abundância de palmeiras, para Gomes (2011) a região possuía dezenas de mocambos, e as pessoas sobreviviam de frutas, plantações, raízes e da caça. A produção oriunda do quilombo não servia apenas à comunidade, mas, excessos eram vendidos ou trocados por matérias primas diferentes com lavradores ou moradores que moravam próximo, segundo a autora na metade do século XVII a população no quilombo dos palmares estava entre seis e oito mil pessoas, já para Munanga e Gomes (2006) a população passava das 30 mil pessoas. Com crescimento dos quilombos e as diversas rebeliões nas fazendas os senhores de escravos temiam por uma debandada maior que certamente Ihes causariam prejuízos, preocupados começaram a pressionar o governo que ordenou a primeira investida sobre o quilombo palmares no ano de 1602. $\mathrm{Na}$ época a principal liderança do quilombo era GANGA-ZUMBA que segundo Mattos (2012) liderou o quilombo de 1645 a 1678. Foram diversas expedições militares na tentativa de acabar com o quilombo eliminando de vez com as ameaças sofridas pelos senhores de escravos. Estima-se que foram mais de 30 expedições militares contra palmares, até que na tentativa de resolver o problema o governo tentou a assinatura de um tratado com o líder dos palmares na época Ganga-Zumba. $O$ trato definia que os escravos que a li viviam deveriam mudar-se para outro local, o líder dos palmares 
aceitou o que não agradou toda população que viviam ali, segundo Gomes (2011) esse tratado foi o ápice para a guerra interna dentro do quilombo. E dentro dessas revoltas internas ZUMBI passa a destacar-se como liderança.

Ganga Zumba mudou-se para o local chamado CUCAÚ, e parte da população de palmares o seguiu. No ano de 1678 o Ganga-Zumba foi assassinado de forma misteriosa, acredita-se que por envenenamento, a partir de então Zumbi assume o comando do Quilombo e retorna a palmares e começa a lutar por seu território, segundo Souza (2012) "Zumbi liderava os seus seguidores de maneira firme e combativa" (pág. 73). Uma nova fase de lutas inicia em 1692 no comando do bandeirante Domingos Jorge Velho, com o apoio do governo e de diversos fazendeiros, as tropas do bandeirante contavam com milhares de homens e canhão, o que culminou com o fim de Palmares no ano de 1694. Segundo Mattos (2012) após várias investidas o quilombo foi destruído em 1694 com a morte de mais de duzentas pessoas e quinhentos capturados. Durante as investiduras militares Zumbi e outros escravos conseguiram fugir, o mesmo resistiu até 1695 quando em uma emboscada foi morto e teve sua cabeça decepada e exposta em praça pública. A vontade de liberdade não morre com Zumbi, em diversos lugares da colônia os levantes de escravos ganhavam força. Durante os mais de três séculos de escravidão no Brasil, foram diversas tentativas na busca pela liberdade por parte escravos, ex-escravos e abolicionistas que já surgiam mesmo que de forma isolada, o que de certa forma pressionava não só o grande, médio e pequenos donos de escravos como também o governo e toda elite aristocrata.

Já despontavam no longe horizonte os novos tempos, esses que trariam a liberdade àqueles que tanto lutavam. No ano de 1822 o Brasil que até então era colônia de Portugal, consegui a sua independência política. A pós a coroa portuguesa pressionar o príncipe regente $\mathrm{D}$. Pedro I e sua esposa Leopoldina a retornarem à corte de Portugal. A assinatura que definia o desligamento da colônia brasileira do reino de Portugal foi dada por Leopoldina, cabendo ao príncipe, que voltava de viagem de São Paulo declarar sobre as margens do Rio Ipiranga o grito de independência. Foi A partir desse período que passou a ter muitos levantes de grupos opositores ou 
favoráveis ao regime imperial, reivindicações de melhores salários, saúde emprego, moradias dentre outas necessidades que a população carecia. Nesse período crescia também a luta dos negros em prol da liberdade, apoiada por grupos abolicionistas que condenavam o regime escravocrata que ainda imperava na vida e na sociedade brasileira.

Os dois anos subsequentes à conquista da independência as classes minoritárias dos negros ganharam força, e em 1824 o governo assina a primeira constituição brasileiro como estado independente e define que todos os homens livres seriam considerados cidadãos além de libertos nascidos ou naturalizados brasileiros com igual acesso civil, diferenciando apenas em direitos políticos. Mattos (2012) diz que foi aprovado em 1831 por pressão da Inglaterra que era parceira comercial do Brasil alei que proibia o tráfico de escravos e que todos que chegara a partir daquela data seriam considerados livres. No entanto a lei foi parcialmente ou totalmente descumprida já que entre os anos de 1831 e 1850 entraram no Brasil cerca de 500 mil escravos.

A intensificação das revoltas escravas juntos as imposições e pressões de países como a Inglaterra fez com que fosse aprovada em 1850 a lei denominada de "Lei Euzébio de Queiroz" que por pressão da Inglaterra, que checou a atacar à costa brasileira, determinava que o tráfico de escravos fosse comparado à pirataria e como tal deveria ser combatida no rigor da lei. Com a assinatura dessa lei as colônias produtoras passaram a ter prejuízos nas suas produções, pois não conseguiam novos trabalhadores e os que já tinham não davam conta do serviço, já que a economia e produção estavam em um momento de expansão. Nesse período iniciou-se o chamado "trafico interprovincial" que consistia no deslocamento de escravos de uma província para outra dentro do território brasileiro. Em 1854 foi assinado o decreto № 731 conhecido como "lei Nabuco de Araújo" que intensifica o cumprimento da lei Euzébio de Queiroz, passando a responsabilidade a marinha, a função de processar e julgar quem transcendesse ou violasse a lei.

Vinte anos depois da assinatura da lei de 1850 acontece um novo feito, é assinada uma nova lei que considerava que todos os escravos nascidos a partir daquela data estariam livres por força da lei. A mesma recebeu o nome de "Lei do Ventre livre", que 
foi apresentada a câmara dos deputados em 12 de maio de 1871 e promulgada em 28 de setembro do mesmo ano. Para Mattos (2012) a lei garantia em termos gerais que filhos de escravos nascidos a partir daquela data estariam livres. Ela também garantia a criação "de um fundo de emancipação nas províncias para a compra da liberdade de escravos e reconhecia ao escravo o direito a ter economias/ pecúlio e a alforria, independentemente da vontade dos senhores donos de escravos" (pág. $78,79)$. Nascia a esperança que a escravidão acabasse de forma definitiva e trouxesse liberdade a pessoas que na sua história de vida carregava o peso do sofrimento.

Diante das pressões internas e externas ao governo, principalmente internacional pela abolição, o governo decide promulgar a "Lei dos Sexagenários" conhecida também como "Lei Saraiva Cotegipe", por № 3.270 promulgada em 28 de setembro de 1885. $\mathrm{Na}$ sua estrutura definia-se que todos os escravos com 60 anos ou mais seriam libertos. Deliberava também que aos senhores de escravos libertos caberia uma indenização que seria paga pelo próprio escravo, dessa forma o liberto era obrigado a trabalhar mais três anos muita das vezes tendo a sua liberdade definitiva só a partir dos 65 anos. Muitos desses escravos libertos continuavam em situação de escravidão ou servidão, por não ter para onde ir ou como se manter, além de já ter uma idade avançada para os trabalhos braçais. A lei sexagenária adiou por mais um ano a assinatura da "Lei Áurea" que foi promulgada em 13 de maio de 1888. Sob № 3.353, "lei Imperial". No ápice da lei de forma curta e sucinta diz que: "É declarado extinta desde a data desta lei a escravidão no Brasil. Revogam-se as disposições em contrário".

A lei foi aprovada pela então princesa Isabel, no entanto essa consolidação era fruto de muita luta e desafios dos movimentos abolicionistas que se intensificaram na década de 80 no século XIX. Para Mattos (2012) lideranças como Joaquim Nabuco, Luís gama, José do patrocínio e André Rebouças, foram fundamentais na abolição escravista no Brasil. O que vale lembrar que muitos livros didáticos trazem em seus escritos textos que dão "credito" da liberdade escrava a princesa Isabel, como a "única defensora dos fracos e oprimidos". O que concerne aqui é relatar que além das pressões externas pelo fim da escravidão em território brasileiro, às lutas internas 
foram fundamentais para tal fim. As grandes fazendas já sofriam com grandes fugas o que faziam com que os donos de escravos propusessem acordos aos seus cativos para que ficassem na fazenda trabalhando em troca de salários e moradia. Mesmo antes da assinatura da lei algumas províncias já haviam declarado fim da escravidão.

O Brasil foi um dos últimos países a declarar o fim da escravidão. Foram mais 300 anos de sofrimento torturas e mortes. Uma nova vida ou forma de viver começa a surgir. Como ocorreu a adaptação de ex-escravos que tinham apenas o trabalho forçado e de repente se ver sem emprego, moradia, sem-terra para trabalhar, sem dinheiro ou qualquer outro benefício que não fosse à liberdade? Como deixar de ser escravo e viver em uma sociedade que o via apenas como servo/cativo? O que mudou na vida da sociedade negra que em 1888 vivia em um regime imperial e no ano seguinte a partir de um golpe militar passa a viver em um país republicano? Essa mudança facilitou ao negro a sua convivência em sociedade?

\section{A VIDA APÓS A ABOLIÇÃO}

A luta de resistência escrava tinha diferentes formas e participantes, muitos morreram e não alcançaram a tão sonhada liberdade, outros conseguiram, mas viram-se presos ao passado.

Após a assinatura da "Lei Áurea" iniciou-se no Brasil um novo e longo período de adaptação de escravos à liberdade que em sua maioria não tinham onde viver e trabalhar o que segundo Mattos (2012) provocou o ingresso dos mesmos no mercado livre onde buscavam ganhar e produzir seu sustento. Nesse mesmo período segundo a autora o governo atendendo interesses de cafeicultores, promoveu a campanha de "branqueamento" da população, já que devido ao longo período de escravidão no Brasil muitos negros existiam nesse território, onde buscavam formar famílias e perpetuar sua cultura. $O$ governo pretendia eliminar a herança africana existente no país.

Após mais de três séculos de escravidão, que fez com que o país crescesse, os exescravos eram vistos como indesejáveis na nova sociedade brasileira, o que para 
Mattos (2012) "o negro deveria ser excluído da sociedade brasileira sendo proibido a sua entrada no país" (pág. 186). Com isso a imigração europeia foi incentivada com o intuito de branquear a sociedade brasileira, para a autora o governo republicano incentivou essa imigração disponibilizando recursos próprios para tal fim, com a intenção de excluir o negro do mercado de trabalho formal. Esse foi um dos primeiros desafios pós-abolição, presenciadas e vividas pelos negros que ainda contou com políticas sociais excludentes e cada vez a cor da pele interferia na classificação social e legitimava a desigualdades.

O que não distância da realidade atual, as dificuldades enfrentadas pela população negra na esfera social. Para Dantas Mattos e Abreu (2012) os negros também enfrentaram restrições, no acesso à educação, as vagas de emprego além de sofrer violência policial. Para os autores "essas práticas discriminatórias existentes no período pós-abolição e a ausência de políticas públicas especificas para recém-saídos dos cativeiros e seus descendentes colocaram a população negra em situação de desvantagem, limitando seus ganhos sociais [...] que já eram bastante restritos" (pág. 88). Após a abolição o ex-escravo passou a lutar por sua liberdade ainda mais, pois buscava por: liberdade social, igualdade de direitos, respeito, reconhecimento e outros fatores que valorizassem a contribuição e participação do negro na formação da sociedade brasileira.

A luta do negro liberto está em grande parte nas questões sociais de respeito e respaldo em direitos adquiridos a partir de muitas lutas coletivas, organizadas, formais e informais. No atual contexto social problemas como racismo, preconceito social estratificação social são fatores que distância a população negra da equiparidade social e econômica tendo como referência a população branca. Embora a constituição brasileira de 1988 e a declaração dos direitos humanos 1948 definam que todos os cidadãos são iguais independentemente de: sexo, raça, cor, idade entre outros, não é a atual realidade social em que vive o negro.

Para entendermos a disparidade entre negro e branco precisamos entender o conceito de raça, preconceito, discriminação e racismo. Segundo Munanga (2006) o termo raça depende de como é utilizado, dependendo do contexto pode-se ter diferentes 
conotações, cabemos definir aqui que se trata do ser humano de pessoas socialmente excluídas, por tanto o autor descreve o termo como sendo "a identificação de raças é, na realidade uma construção social produzida no interior das relações sócias e de poder ao longo do processo histórico" (pág. 176). Segundo o autor a cultura é um dos fatores de maior identificação de raça, cabe identificar que o termo que melhor nomeia o segmento da população negra é "etnia" que segundo Munanga (2006) "é um grupo social cuja identidade se define pela comunidade de língua, cultura, tradições, movimentos, historias e territórios”... (pág. 177). Ressalta-se que a substituição do termo raça por etnia está ligada a relação em que o termo raça esteve ligado à servidão e subserviência e dominação política e cultural. Porém, o autor reforça que o uso dos conceitos deve ser de forma complementar e nunca separado, pois os mesmos representam a complexidade de entendimento do negro na história do Brasil.

O preconceito e a descriminação são realidades vividas pela população negra não apenas antes da abolição, mas, mais ainda nos dias atuais. Esses fatores muitas das vezes determinam a situação social do negro na visão do discriminador. Devemos distinguir o que é preconceito e descriminação. Preconceito pode ser definido como posturas ou opiniões que algum individuo ou grupo tem ou mantem em relação a outros grupos ou pessoas. Trata-se de visões pré-concebidas de um indivíduo preconceituoso baseando em rumores ou falta de conhecimento e está ligado a qualquer setor da sociedade ou algo que julgarem sem conhecimento prévio, já quando falamos de preconceito racial, Munanga (2006) define como "julgamento negativo e prévio que membros de uma raça de uma etnia, de um grupo, de uma religião ou mesmo de indivíduos constroem em relação ao outro" (pág. 181). Preconceitos ou as formas de preconceito baseiam-se em sua maioria em estereótipos, esses que por sua vez tratam se de visões embutidas em olhares culturais ou sociais o que torna difícil desfaze-los mesmo tratando-se de distorções inflexíveis e grosseiras da realidade vivida por determinado grupo social.

O preconceito é algo socialmente construído e disseminado nas relações entre pessoas ou grupos humanos que estão fechados em uma determinada opinião ou ponto de vista, sem nenhuma abertura ao conhecimento, o que possivelmente seria 
uma forma de reavaliar sua visão. A cotidianidade atual apresenta diferentes formas de preconceitos, seja nas ações, olhares, na forma de comunicação. Essa perpetuação do preconceito principalmente racial faz entender que a nossa sociedade de diferentes formas produz a desigualdade entre os indivíduos. Só desconstruiremos o preconceito se tivermos o objetivo de desconstrui-lo. Quando falamos de descriminação estamos explicitando o comportamento que um individua ou grupo tem em relação a outro.

De fato descriminação deriva ou tem como base o preconceito. Quanto trata de descriminação racial é definido como o ato de diferenciar, distinguir e pode ser tratado como efetivação do preconceito contra ou de um grupo sob outro, principalmente na inferiorização do negro, frente às ações e oportunidades, disponibilizadas socialmente. Essa inferiorização do negro frente a sociedade recebe o nome de racismo que segundo Munanga (2006) "é um comportamento, uma ação, resultante da aversão por vezes, do ódio em relação a pessoas que possuem um pertencimento racial observáveis por meio de sinais tais como a cor da pele, tipo de cabelo, formato do olho etc." (pág. 179). Para o autor o racismo é resultado da crença que raças ou tipos humanos são superiores ou inferiores a outros.

O racismo é a ramificação do preconceito que se baseia em distinções físicas que tem significado social. O mesmo apresenta diferentes categorias dentre elas; o racismo institucional que trata da negação coletiva seja em grupo ou organização que presta ou desenvolve serviços profissionais para pessoas, por causa da cor, cultura ou origem étnica. Posturas de profissionais como desconsideração, ignorância, descriminação através de preconceitos.

São grandes representantes do racismo institucional e acabam por colocar minorias étnicas em situações de vulnerabilidade frente aos serviços prestados. Com as novas questões sociais e culturais tem aparecido como uma nova forma de racismo. Nos dias atuais a cultura e a religião tem sido a forma que muitos racistas encontram para legitimar suas visões e pensamentos, acreditando na superioridade de crença e cultura. 
De certo que as múltiplas formas de racismo têm efeito muita das vezes devastadoras na construção social, pois atualmente é evidenciado de maneiras diferentes, e em diferentes seguimentos da população. No entanto à busca por respeito e reparação social e igualdade entre negros e brancos é que a Constituição Federal Brasileira de 1988 em Direitos e Garantias Fundamentais define em seu Artigo 5은II que "a pratica do racismo constitui crime inafiançável e imprescritível, sujeito a pena de reclusão, nos termos da lei (Brasil 1988).

O que a constituição apresenta é a criminalização de atos racistas que acontecem diariamente muita das vezes de forma velada, no entanto muito desses casos não chegam ao crivo da justiça, no Brasil o mito da "democracia racial" foi um dos maiores empecilhos para a construção de políticas públicas de direito e respeito que fossem no passado e no presente efetivado de forma significativa. $O$ que não favoreceria apenas os negros mas todos aqueles que fazem parte de uma sociedade que foi construída geograficamente, politicamente e economicamente tendo como base a mão de obra escrava. Hierarquização, descriminação, a inferiorização e o preconceito são perspectivas, atitudes ou pensamentos ora inconscientes ora velados e desestruturante, e mantem seguras estruturas de desigualdades econômicas e sociais entre o negro e o branco no Brasil. É importante desvelarmos os ideais em favor da equiparidade e igualdades sociais e por se buscar por aplicações de políticas públicas voltadas para tais questões. O racismo não está só na história do negro ou do Brasil, mas do que nunca este presente na contemporaneidade social.

\section{AS REVOLTAS E OS MOVIMENTOS}

A conquista de direitos sociais foi e continua a ser uma batalha árdua da população negra, pesquisas evidenciam a presença dos mesmos em grandes manifestos, protestos e revoltas para DANTAS 2012 os negros reivindicavam melhor alimentação, salários, terras para o cultivo, reclamavam por igualdade de tratamento, reconhecimento e autonomia. Os autor afirmam que desde a abolição a população negra já estavam presentes nas frentes reivindicatórias como "a guarda negra, a guerra de canudos, a revolta da vacina a eleição de Monteiro Lopes para a câmara dos deputados (RJ)" dentre outros, contudo os movimentos negros forma intensificar- 
se a partir do século $X X$, entre as décadas de 20 e 30 foram criados diferentes organizações políticas como a Frente Negra Brasileira (FNB) que foi formado a partir dos movimentos já existentes como "imprensa negra" os grêmios, os clubes e associações negras. A FNB foi a mais importante organização de movimento negro nas primeiras décadas do século XX segundo alguns historiadores o grupo chegou a unir mais de 40 mil associados em diferentes estados do Brasil.

Criou-se também em 1944 no Rio de Janeiro o Teatro Experimental Negro (TEN), que foi fundado por Abadias no Nascimento e também o grupo, União de Homens de Cor (UHC) criado em 1943 em Porto Alegre. Todos esses movimentos tinham como característica em comum a inclusão do negro na sociedade. No ano de 1978 em meio ao regime militar (1964-1985) foi criado o Movimento negro Unificado (MNU) em São Paulo o movimento contou com diferentes estados essa criação segundo Dantas (2012) foi fundamental "na consolidação do movimento negro contemporâneo" (pág. 104). O período que vai de 1964 a 1985 foi conturbado não só para os movimentos negros, mas para toda sociedade. O MNU lutava por uma nova sociedade ou amenos por novos valores sociais, com a participação de todas, mas principalmente que valorizasse o contexto social do negro, acabando quem sabe com o mito de "democracia racial". Segundo Dantas (2012) "a perspectiva de luta que passou articular as categorias de (raça) e (classe) e uma importante característica da política negra que se constituiu no Brasil a partir da década de 1970" (pág. 105).

Os movimentos negros ocorridos no final do século XIX até os dias atuais foram precedidos de revoltas lideradas por escravos ou por ex-escravos e abolicionistas que junto com grande parcela da população negra lutavam por diversos direitos que eram negados aos negros. É importante lembrar que os negros nunca formam passiveis a condição de servidão torturada ou não. Nesse contexto de luta pelo reconhecimento do trabalho e pela não exclusão social é que ocorreu em 25 de janeiro de 1835 a chamada "Revolta dos Malês" no estado da Bahia, um dos movimentos pro negro e ex-escravizados, que naquele momento histórico não tinham donos mas estavam escravizados pelo seu próprio passado. A revolta dos Malês reivindicava não somente a estrutura existente em que o negro era excluído como também o aceite do culto de 
religiões de origens africanas. A revolta que durou apenas algumas horas renovou ou imprimiu naqueles homens e mulheres o desejo de mudança, de liberdade e dignidade na sociedade que tanto batalhou para construir. Outras revoltas como: "Revolta dos Alfaiates" na Bahia em 1798, a "Cabanagem" no Pará de 1835-1840, a "Sabinada" na Bahia de 1837-1838 e a "Balaiada" no Maranhão de 11838-1841, foram as mais conhecidas no contexto nacional e que despertou não só afigura do negrona sociedade como também da elite, que deveria buscar respeitar e partilhar direitos com toda população negra.

As lutas forma frequentes mesmo após a assinatura da "Lei Aurea" em 1888, de fato negros estavam libertos por força da lei, mas tinha em sua memória o passado escravizado, que perdura até os dias atuais na sociedade afrodescendente. $O$ fato de ter uma lei que libertou o negro, ela e a sociedade não garantiam os mesmos direitos e oportunidades entre os negros e os brancos. Seria então necessário continuar a luta não para deixar de ser escravo, mas pela igualdade já que não eram, mas escravos. O contexto social, econômico e estrutural não facilitava a inserção do negro na sociedade, se não como um cativo. É fato destacar que os diversos movimentos por igualdade fizeram e fazem parte da história do Brasil.

Dentre os grandes movimentos e revoltas negras ocorridas no Brasil desde a sua colonização não podemos esquecer-nos da participação da mulher como papel fundamental frente a movimentos que reivindicavam não só a igualdade de direitos entre negros e brancos, mas também a igualdade de gênero o que para Munanga (2006) diz que a mulher enfrenta dupla descriminação "ser mulher em uma sociedade machista e ser negra numa sociedade racista" (pág. 133). A partir dos anos 60 no século XX, as mulheres passam a desempenhar grandes papeis frente a movimentos, a ONGs, na busca pelo reconhecimento. A sensibilidade em identificar o valor feminino está em compreender o papel da mulher na sociedade que no período da escravidão vivia sobre trabalho forçado. No final do século $X X$ ela desponta não mais como dona de casa, mas por quem busca crescer em espaços de trabalho com igualdade de reconhecimento entre homem e mulher. 
Um dos problemas que o negro enfrentou e enfrenta é o racismo e o preconceito social, o que torna a luta pela igualdade, cada vez mais necessária e focada no coletivo. As relações construídas entre brancos e negros sempre foi de servidão (negro ao branco), não que o negro buscasse essa condição, mas atitudes de classes que se denominam superiores as outras empunhavam no cotidiano do negro. A partir das lutas e dos movimentos que viveu e vive o Brasil, surgem à necessidade de se construir ações que visassem à equiparação de direitos e respeito social. As chamadas "ações afirmativas" que por sua vez não só busca igual o direito entre negros e brancos como corrigir erros do passado, visando valorizar o negro na sociedade.

Essas ações constituem-se como práticas sociais de combate à discriminação racial, buscando à igualdade e oportunidades para todos. Esse conjunto de políticas públicas pode conter em sua estrutura ações públicas ou privadas que pode ser compulsória ou facultativa em corrigir as desigualdades impostas a grupos sociais ou étnico/raciais. Dentre as ações afirmativas estão à legislação brasileira que tem em seu Código Penal, no ART. 140 parágrafos 3 injuria e descriminação, como atos reprováveis e sujeitos a sanções da lei. Constam também como leis afirmativas:

Lei 7.716/89 crimes de racismo; lei 7.347/85 ações civil pública; Lei 9.455/97 contra tortura; Constituição Federal de 1988 art. 5 XLII; Lei 12.288/10 estatutos da igualdade racial; Lei de Diretrizes e Bases da Educação Nacional (LDB) 939.4/96; Parâmetros Curriculares Nacionais (PCN) 1996; Lei 11.645/2008; Lei 10.639/03. Etc.

As criações de cotas em universidades reservam para negros em concursos públicos, são também algumas das conquistas frente às ações afirmativas no século XXI. As ações afirmativas tratam o caráter político cultural e pedagógico, de um lado buscam por meio da legislação penal punir todo e qualquer ato de descriminação por outro lado à igualdade de oportunidades para todos. Essas ações buscam acelerar o processo histórico que por si só poderia demorar décadas, ou até séculos, na reparação de políticas públicas voltadas aos negros e aos menos favorecidos. 


\section{DA TEORIA A PRÁTICA}

As diferentes ações afirmativas organizadas e implantadas do Brasil tinham/tem por objetivo corrigir o trato social dispensado a população negra, que passou de escravos e excluídos, pessoas que não tem os mesmos direitos nem o reconhecimento de luta e formação social e cultural. A partir dos diferentes contextos em que o negro lutava pelo respeito é que foi criada a Lei 10.639 de 2003, medida de ação afirmativa sancionada pelo então presidente da República Luiz Inácio Lula da Silva em 09 de janeiro de 2003.

A lei que já vinha sendo discutidos anos anteriores, por força dos movimentos negros traz na sua totalidade a obrigatoriedade do ensino de História e Cultura Afro-brasileira e Africana, com a inclusão obrigatória nos currículos das escolas públicas e privadas do ensino básico, além de determinar dia 20 de novembro como "dia nacional da consciência negra". Essa lei foi responsável pela alteração nas Diretrizes Curriculares Nacionais, que consta como uma grande vitória dos movimentos negros.

Em parecer CNE 003/2004, busca a promoção de ações por igualdade racial segundo o mesmo em suas questões introdutórias:

Parecer procura oferecer uma resposta, entre outras, na área da educação, à demanda da população afrodescendente, no sentido de políticas de ações afirmativas, isto é, de políticas de reparações, e de reconhecimento e valorização de sua história, cultura, identidade. Trata, ele, de política curricular, fundada em dimensões históricas, sociais, antropológicas oriundas da realidade brasileira, e busca combater o racismo e as discriminações que atingem particularmente os negros. Nesta perspectiva, propõe à divulgação e produção de conhecimentos, a formação de atitudes, posturas e valores que eduquem cidadãos orgulhosos de seu pertencimento étnico-racial - descendentes de africanos, povos indígenas, descendentes de europeus, de asiáticos para interagirem na construção de uma nação democrática, em que 
todos, igualmente, tenham seus direitos garantidos e sua identidade valorizada. (BRASIL 2004).

A partir de então, os estabelecimentos de educação básica passam a ter um documento que norteia discute e aprofunda o fazer pedagógico. Segundo Fonseca (2011) grupos de intelectuais, movimentos sociais, movimentos negros, acreditam que a escola pública desempenha papel fundamental na construção da educação para a diversidade. Frente ao novo contexto a disponibilidade de cursos de formação e parcerias com universidades buscam formar o professor par o trato com a diversidade em âmbito educacional. O que mudou nesse período em que a lei entrou em vigor? $\mathrm{O}$ que falta para a sua efetivação? Os professores têm o aporte fundamental para o trato coma diversidade? E os alunos?

As políticas sociais de reparação e reconhecimento da história negra na construção social brasileira detém um conjunto de direitos que foram negados ao longo de muitos anos de sofrimento.

As noções de cultura, pluralidade e diversidade cultural passam ao fim da década de 90 a estar pressente nas normas que o ministério da educação e cultura determina ao ensino de História no ensino fundamental e médio assim como as relações étnicoraciais que alcança patamares sociais e políticos sempre imaginados pelos movimentos negros.

Os Parâmetros Curriculares Nacionais (PCNs) que desde 1997 já atestavam para a pluralidade cultural junto às diretrizes curriculares, toma força de lei determinando a representatividade do ensino de História e Cultura Afro-brasileira e Africana, e concentra em sua estrutura caminhos para reverter características estereotipadas dos negros.

As diretrizes curriculares determinadas pelo parecer 003/ 2004 traz para o âmbito escolar importantes discussões referentes às relações raciais no Brasil e principalmente desvelar o racismo que outrora se escondia no "mito da democracia racial", para entendermos em sentido geral o que é democracia racial, trata-se da ideia 
que todas as raças são iguais assim como os direitos, e essa percepção surgiu entre as décadas de 30 e 40 quando se opôs a teorias antirracistas.

As novas diretrizes não foi um desafio apenas social quanto a sua implementação efetiva, mas também aos profissionais de história como pesquisadores e professores, pois convocam de forma efetiva a participação desses profissionais no pensar e refletir a história da cultura afro-brasileira e suas diferentes dimensões no campo da pesquisa e do ensino/aprendizagem. O que até então se tratava de um ensino complexos com diferentes temas, mas onde a história do negro não tinha referência ou relevância, passa a debates e conceitos como: identidade negra, raça, democracia racial, cultura negra, dentre outros campos que estruturam a base de estudos da história e cultura afro- brasileira e africana.

O que a lei 10.639 traz na sua estrutura não é apenas um caminho a ser seguido, mas a obrigatoriedade do ensino e o reconhecimento que no Brasil não há apenas a história do branco, e que a miscigenação não deu fim as diversas lutas por igualdade e respeito. O ponto central da lei é a sua real implementação no sistema educacional, a lei foi aprovada em Janeiro de 2003, porem a sua efetivação e desenvolvimento total está sob o julgo dos profissionais que lidam com ela dentro do ambiente escolar seja desde a produção de um currículo diversificado como projeto político pedagógico com determinado fim.

A concretização da lei não deve está exposta apenas a subjetividade do profissional, precisa em sua totalidade está a serviço da formação dos alunos para a diversidade o reconhecimento histórico social da luta negra na construção social, política, econômica e demográfica do Brasil. A lei encontra empecilhos como profissionais despreparados para o trato com a diversidade, o preconceito quanto ao ensino da religião de matriz africana por partes de profissionais que não a ver como religião e projetos políticos pedagógicos inflexíveis.

Como afirma Nelson Mandela "a educação é a arma mais poderosa pela qual se pode mudar o mundo", é na educação que devemos buscar o aporte necessário para os novos conhecimentos e respeito a cultura afro-brasileira e africana. O século XXI é 
protagonista de muitas lutas e conquistas sociais, movimentos coletivos e organizados, são responsáveis por grandes mudanças sociais, políticas e econômicas.

Como visto o parecer 003/04 busca, através de ações afirmativas as chamadas políticas de reparação reconhecer e valorizar a história, cultura e identidade dos povos africanos e seus descendentes. Esse documento trata em políticas curriculares subsidiadas em dimensões antropológicas, históricas sociais que vem da realidade brasileira. De forma a combater o racismo e as diversas formas de descriminação que em sua particularidade atingem o negro. $O$ documento supracitado, atenta para a divulgação e produção de conhecimentos onde o ser humano reveja posturas, valores e atitudes quanto ao pertencimento racial de si e do outro. Segundo as Diretrizes curriculares da Educação Básica (2013) "a obrigatoriedade de inclusão de História e Cultura Afro-brasileira e Africana nos currículos da educação básica trata-se de decisão política, com fortes repercussões pedagógicas, inclusive na formação de professores (pág. 503) (grifo meu)".

Cabe ressaltar que a "decisão política" não se trata de política partidária, mas sim das diversas lutas e questionamentos dos movimentos negros que desde o século $\mathrm{XX}$ discutem e almejam a valorização e respeito à comunidade negra. Com base no texto das diretrizes a consciência política e histórica da diversidade têm em seus princípios, a compreensão de igualdade de direitos entre todos os sujeitos, compreendendo que a sociedade é formada de pessoas que pertencem ou se identificam com diferentes grupos étnico-raciais, valorizando assim a história dos povos africanos como também a cultura e contribuição dos mesmos na formação do Brasil.

O entendimento e respeito à diversidade é a força necessária para desencadear um "processo de afirmação de identidades, de história negada ou distorcida", o que contribuirá no desenvolvimento de ações educativas voltas as perspectivas que segundo DCEB 2013 que diz que o ensino deve evitar distorções, envolvendo o passado e presente e o futuro no âmbito da construção de experiências. Segundo o texto "o ensino de história e Cultura Afro-brasileira e Africana se fará por diferentes meios em atividades curriculares ou não" (pág. 505). O que culminará com a 
contribuição da própria sociedade na transformação da visão e da educação para negros.

O DCNEB possui dimensões normativas, porém não fechadas, e que possam a partir de sua base se propor novos caminhos para o ensino e o aprendizado educacional. Para o conselho Nacional de educação através da Resolução №1 de 17 de junho de 2004, define-se a obrigatoriedade do ensino de conteúdos e atividades curriculares que tenham por base a cultura e história africana e afro-brasileira sob pena de funcionamento da instituição servidora.

\section{COMUNIDADES REMANESCENTES DE QUILOMBO E O PROCESSO EDUCACIONAL}

As comunidades quilombolas assim como seu longo processo histórico de lutas fazem parte do contexto não só do Brasil como também do mundo. Ao longo dos tempos os negros junto a outros povos ou comunidades que em sua particularidade são considerados tradicionais buscam através de processos políticos e sociais uma mudança tanto social como juridicamente revendo as várias formas de interpretações das leis e suas aplicações, pressionando assim o estado a rever as relações entre igualdade e pluralidade.

De acordo com a constituição de 1988 em suas Disposições Gerais no Artigo 68 é definido em relação aos quilombolas: "aos remanescentes das comunidades dos quilombos que estejam ocupando suas terras é reconhecida a propriedade definitiva, devendo o Estado emitir-Ihes os títulos respectivos" BRASIL (1988), assim como o

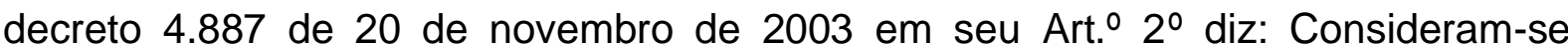
remanescentes das comunidades dos quilombos, para os fins deste Decreto, os grupos étnico-raciais, segundo critérios de auto atribuição, com trajetória histórica própria, dotados de relações territoriais específicas, com presunção de ancestralidade negra relacionada com a resistência à opressão histórica sofrida ( BRASIL 2003)

É fato que a constituição brasileira abriu caminhos para novas conquistas das comunidades tradicionais, valorizando a cultura e a arte de povos quilombolas, o 
Estado visa "inserir" socialmente de forma igualitária e com respeito. Nos Artigos 215 e 216 da CF, garante a promoção e proteção patrimonial cultural brasileira definindo que "bens de natureza material e imaterial, tombados individualmente ou em conjunto, portadores de referencia a identidade, à nação, à memória dos diferentes grupos formadores da sociedade brasileira" (BRASL 1998).

A constituição de 88 não só ampliou os direitos como estendeu e legitimou as práticas culturais de forma a assegurar o culto religioso de matriz africana e a proteção do patrimônio cultural brasileiro. No entanto foram grandes questionamentos que ocorreu com a titulação individual ou coletiva de terra de remanescentes, que por sua vez causaram diferentes conflitos e desestruturou a perspectiva de mudança das comunidades remanescentes, o que torna cada vez mais difícil a legitimação dos mesmos e consequentemente, os povos são privados de direitos sociais e culturais que Ihes são constitucionalmente outorgados, para Mattos, Dantas e Abreu (2012) o decreto 4.887 foi à concretização de diversos esforços em prol do reconhecimento de direitos de um povo. Porem muitas das dificuldades ainda existe, para que muitas dessas comunidades sejam de fato legitimada como "comunidades remanescente de quilombo". Segundo a Fundação Cultural Palmares (FCP) através da portaria 138/2019 publicada no dia 02 de agosto de 2019 o Brasil tem cerca de 3.386 (três mil trezentos e oitenta e seis) comunidade remanescentes de quilombos, segundo a mesma portaria, 38 comunidades aguardam a "visita técnica" e cerca de 192 está em análise técnica. O decreto $\mathrm{n}^{\circ} 6.040$ de sete de fevereiro de 2007 define que a priori as políticas Nacionais de Desenvolvimento sustentáveis dos povos de comunidade Tradicionais é um caminho legitimo que visa uma maior inclusão desses grupos sociais e em seu artigo $3^{\circ}$ (...) I.

Povos de comunidade tradicionais: grupos culturalmente diferenciados e que reconhecem como tais, que possuem formas próprias de organização social, que ocupam e usam territórios e recursos naturais como condições para sua reprodução cultural, social, religiosa, ancestral e econômica, utilizando conhecimentos inovações e práticas geradas e transmitidas pela tradição (BRASIL, 2007). 
Existem políticas públicas que são destinadas aos quilombos considerando as relações sócias, políticas, culturais e educacionais condicionantes aos quilombolas. Nessa concepção a questão da Educação Escolar quilombola toma frente a questões de preservação cultural e avanços sociais. Para tanto a sua implementação deve darse de forma acompanhada e democrática entre o poder público e as organizações de comunidades quilombolas, levando em consideração a realidade vivida pelas comunidades e o passado de seus ancestrais.

Grande parcela das comunidades foi construída com muita luta enfrentando o racismo, a luta pela terra, respeito à diversidade sociocultural de forma a garantir a cidadania e desenvolvimento da comunidade. Segundo a CFB artigo 210 que diz que "serão fixados conteúdos mínimos para o ensino fundamental, de maneira a assegurar formação básica e respeitar aos valores culturais e artísticos, nacionais e regionais" (BRASIL1988).

A educação quilombola levará nas suas diretrizes a formação de seus alunos a partir não só de um currículo geral como principalmente um currículo específico tendo como base os valores e referencias da comunidade, e seus aspectos históricos importantes que reproduz a capacidade e relevância do seu povo na formação da sociedade brasileira. No entanto questões políticas sociais, e a falta de Adequação profissional e até mesmo religiosa para o trato com a educação quilombola faz com que a implementação dessas políticas educacionais valorativas aos quilombolas sofra na sua execução.

A interação entre as comunidades quilombolas e o mundo exterior a elas dá-se exclusivamente por meio da educação que se torna ponto fundante nas relações socioculturais de todo povo. Não precisamos adequar o negro a uma realidade que não o valoriza ou a uma cultura branca, mas sim valorizar a sua cultura, a história negra através da perpetuação de valores, trocados por intermédio da educação. Uma história não está acabada quando ainda se vive ela, passa a partir daí ser o presente, ser atual, esse é o dever da educação quilombola tornar atual, vivida e respeitada a cultura e história do negro no Brasil. Revivendo através da educação já mais 
esquecemos a importância histórica, politica, cultural, econômica, demografia e social que o negro tem na formação do Brasil.

\section{COMUNIDADE QUILOMBOLA DE RAPOSA}

A comunidade é um exemplo de preservação sociocultural e de protagonismo feminino. A comunidade está situada na Fazenda Raposa zona rural do município de Caldeirão Grande Bahia. Segundo Brasileiro 2017 o povoado foi descoberto no ano de 1963. Mas só foi reconhecido como Comunidade Remanescente de Quilombo no ano de 2013, onde teve a sua certificação divulgada no Diário Oficial da União (DOU) em 01 de abril de 2013, reconhecido pela Fundação Cultural palmares (FCP) e registrada no Livro de Cadastro Geral oㅡ 014, Registro ํo 1.782. fl 199 sob processo no 01420.012070/2012-74. Essa certificação reconhece a comunidade como Remanescente de Quilombo, concedendo Ihes o direito a cidadania a direitos sociais a preservação cultural e valorização étnica da comunidade.

A localidade teve a frente de sua formação mulheres que se tornaram protagonista por suas diversas lutas na busca em manter a comunidade e pela conquista da certificação, além de cultivar as suas raízes culturais. Dentre essas mulheres podemos destacar as grandes matriarcas: Vilarinda Maria de Jesus. Quintina Marculino dos Santos e Durvaldina Justina de Jesus, todas filhas ou netas dos primeiros habitantes da comunidade de raposa.

A comunidade foi formada por pessoas que se deslocaram do Quilombo do Tiririca conhecido como "tiririca dos negrinhos" no município de Queimadas também no estado da Bahia, quando em viagens para a cidade de Jacobina para a compra ou troca de utensílios e alimentos, sempre passavam nesse local, que com o tempo, acabaram fixando-se alí e dando o nome da localidade de Raposa, pois todas as vezes que passavam no local avistavam muitas raposas (animal).

$\mathrm{Na}$ atualidade a comunidade de Raposa vive novos tempos após o reconhecimento e autoafirmação além de uma escola dentro da comunidade os moradores são assistidos por políticas públicas oriundas do governo federal, estadual e municipal, 
além de contar com produção própria da agricultura e do artesanato através do extrativismo e da agricultura familiar. Destaca-se dentro da comunidade o plantio da mandioca e o extrativismo do licuri e seus derivados.

\section{RESULTADOS E DISCUSSÕES}

Todo trabalho exige um processo continuo de verificação de resultados consultas de fonte bibliográficas e demais fontes de informações que contribua para o desenvolvimento da pesquisa. A história do negro desde a sua saída do continente africano até a chegada ao Brasil, é baseado em torturas, maus-tratos, doenças, separações, dentre outros fatores que aniquilam a liberdade. O processo histórico do Brasil que rendeu a formação social, econômica e demográfica teve como base a mão de obra africana, que diante da impossibilidade de escolha em querer ser e onde viver.

O Brasil tem mais de cinco séculos de existência dos quais mais de três são escravidão, que teve início segundo os historiadores do final do século XVI e início do século XVII. O negro durante todo esse período não sofreu apenas com os maustratos físicos, mas, mais com a tentativa da diminuição da sua identidade cultural e religiosa. Para o indivíduo é fundamental o reconhecimento de sua origem e a identidade construída socialmente. O negro durante todo esse longo período buscou o respeito e o reconhecimento por parte da sociedade, visto que é um povo na história de um povo, ou seja, os negros na história do Brasil.

A busca por desenvolver políticas de reconhecimento do negro os grandes movimentos e lutas no Brasil feito por movimentos negros, abolicionistas e defensores da identidade negra, culminou com o desenvolvimento de ações afirmativas, políticas públicas para o negro, o que faz a população afro-brasileira ser reconhecida em direitos, cultura, religião e socialmente. A população negra vive uma nova situação social no Brasil, com maior visibilidade, respeito e reconhecimento, embora ainda exista ora de forma velada ora de forma exposta a descriminação, quanto a religião cultura, cor de pele, cabelos e outras características particulares que identifica o negro. 
As ações afirmativas visaram principalmente modificar o meio educacional, para educar a sociedade, através da lei 10.639, buscou implementar no sistema educacional brasileiro a obrigatoriedade do ensino de História e Cultura afro-brasileira e Africana. O que fez com que se modificassem através do parecer 003/04 as Diretrizes curriculares nacionais da Educação Básica. A obrigatoriedade da lei tem a finalidade de reparar questões de descriminação de direitos negados socialmente aos negros ao logo da história do Brasil. No entanto questões ainda existem quando a efetivação da lei dentro do ambiente escolar, o que dificulta a aprendizagem dos alunos sobre a descendência afro-brasileira e africana.

Cabe enumerar algumas perguntas necessárias de reposta que identifiquem as possíveis dificuldades enfrentadas em contexto educacional para a efetivação da lei 10.639. Será que os professores estão preparados para lidar com essas questões dentro da sala de aula? A religião a que os professore pertença pode ser um empecilho para o ensino de história e cultura afro-brasileira e africana dentro da escola? Existe descriminação com relação à religião de matriz africana?

As discussões são fundamentais para o desenvolvimento de ideias e conceitos relacionados a história do negro em contexto de formação da sociedade brasileira. $\mathrm{O}$ contexto sociocultural que da identidade a população negra é uma das características que definem a importância do negro na formação atual do Brasil, participando da formação econômica, demográfica, social e cultural na sociedade brasileira além de contribuições que definem a identidade da população negra no Brasil.

A nova dinâmica social subsidiada pelo desenvolvimento de políticas públicas de reparação e efetivação de direitos tem revisto paulatinamente o grande abismo existente dentro da sociedade, fatores que alimentam dentro da sociedade a capacidade de superação e aceitação, seja direta ou indireta do crescimento da igualdade social. A construção de uma teoria ou de um caminho deve compor o grau de legitimidade de lutas e movimentos que hora a séculos atrás faziam parte dos embates dos negros. O que na contemporaneidade tem tornado cada vez mais visível e aceitável a polarização do querer da inclusão igualitária dentro deum uma mesma 
sociedade, que hora seja constituídas de diferenças grupais, mas que pertencem a uma mesma nação.

A existência de diferentes fatores que arraigaram na sociedade a ideia de submissão está sofrendo dentro das novas políticas públicas a ameaça de existência, centrada na revisão da ótica dispensada pelos diferentes segmentos sociais quanto ao valor e pertencimento social do negro. As novas conjunturas sociais tendem por uma linha de pensamento valorativa, independendo do passado, todos esses novos caminhos são pautados no respeito e na busca pela inclusão social independendo de cor, raça religião etc. para que passe a existir uma sociedade igualitária não apenas na teoria mas principalmente na prática. Não existirá apenas uma visão deturpada, se existir uma visão que corrige.

\section{CONCLUSÃO}

O negro foi peça fundamental na formação da sociedade brasileira e na construção de seu estado, os diversos conjuntos de fatores ocorridos em diferentes épocas e contextos delineou o grau de importância e de dependência do estado para com o negro, em diferentes sentidos, seja ele demográfico, cultural, religioso, social ou outros. Porém o que se revela nos mais diferentes contextos históricos e contemporâneos é que a diáspora tenha se tornado insignificante na ótica de parte da sociedade brasileira, invalidando assim todo o processo de deslocamento por meio inferiorizacão da cultura, da religião e do valor social que o negro teve e tem dentro da sociedade. Os mais diferentes estereótipos arraigados no preconceito e na descriminação faz do negro um ser descriminado dentro do próprio meio. A busca pela ruptura da mais perversa e vil ótica discriminatória da sociedade, passa pelo reconhecimento da figura do negro como o grande engenheiro da formação social brasileira. O sentido que se adquire a partir daí perpassa a ideia de aceitação, e encontra base no respeito ao outro assumindo o direito de igualdade a todo ser humano. Para que esses objetivos sejam alcançados muito mais do que políticas públicas precisam ser criadas, é preciso desvincular-se dos campos teóricos e ganhar estabilidade na prática tendo como sujeitos ativos aqueles que descende dos que sofreram na diáspora. $O$ grande conjunto de valores que caracterizam o negro 
também legitimam as diversas lutas e movimentos desenvolvidos durante séculos na sociedade. A busca pelo reconhecimento culmina na contemporaneidade com ações afirmativas que longe da sua totalidade ascende a esperança de igualdade e respeito. Os sujeitos da história hoje estão próximos da tão sonhada liberdade. Embora as tenha alcançada por meio da lei em 1888 até hoje luta para ser visto. Conclui-se então que muitas perguntas tendem ser respondidas e desafios superados para alcançar majoritariamente a igualdade de direitos. Por tanto o que se entende hoje é que caminhamos a passos largos dentro do campo teórico, buscamos a liberdade, inclusão, igualdade e respeito por meio das palavras, nesse sentido o negro vive em uma sociedade justa e igualitária, no entanto a prática revela-se lenta com perspectivas vindouras tão subjetivas e longe do real. É fato que muito se conquistou, hoje o negro vê-se em novas perspectivas porém, se está muito distante de onde deveremos estar, ou seja, em uma sociedade igual em direitos independentemente de cor, religião, raça, sexo ou idade.

\section{REFERÊNCIAS}

BRASIL. Constituição da República Federativa do Brasil. Ato das Disposições Constitucionais Transitórias - ADCT. Brasília: senado, 1988.

Secretaria de Educação Fundamental. Parâmetros curriculares nacionais : pluralidade cultural, orientação sexual / Secretaria de Educação Fundamental. - Brasília : MEC/SEF, 1997. p.164.

. Lei no 9.394/96, de 20 de dezembro de 1996. Brasília.

. Lei no 10.639, de 9 de janeiro de 2003. Brasília.

Ministério da educação. Conselho nacional de educação. Parecer $\mathrm{CNE} / \mathrm{CP} 3 / 2004$. Diretrizes curriculares nacionais para educação das relações étnico-raciais e para o ensino de história e cultura afro-brasileira e africana. Brasília: MEC, 2004.

. Lei no 12.288, de julho de 2010. Brasília. 
. Plano Nacional de Implementação das Diretrizes Curriculares Nacionais para Educação das Relações Étnico-Raciais e para o Ensino de História e Cultura Afro-brasileira e Africana. Brasília, 2004.

Diretrizes Curriculares para a Educação escolar quilombola. Resolução no 8, de 20 de novembro de 2012. Brasília: Conselho Nacional de educação Câmara de educação Básica (CNE/CEB).

. Diretrizes Operacionais para a educação Básica nas Escolas do campo. Brasília: abril, 2002.

BRASILEIRO, Danielma da S. B. Da Escola no Quilombo à Escola do Quilombo: a prática pedagógica como elemento substancial para fortalecer sentidos de pertencimentos indenitários. Projeto de pesquisa para o programa de mestrado apresentado a MPED. Jacobina-Ba, Uneb. 2016.

CARDOSO, Mauricio. Cerencio, Priscilla. Direitos humanos: diferentes cenários, novas perspectivas - São Paulo: Editora do brasil, 2012

CARNEIRO, sueli. Racismo, sexismo e igualdade no Brasil- São Paulo: selo Negro, 2011.

DANTAS, Carolina Vianna. MATTOS, Hebe. ABREU, Martha. O negro no Brasil : trajetórias e lutas em dez aulas de historia. 1 ed. - Rio de Janeiro : Objetiva, 2012.

FACHIN, Odília. Fundamentos de metodologia, 5 ed. - São Paulo : Saraiva, 2006.

FONSECA, Marcus Vinicius. Silva, Carolina Mostaro Neves da. Fernandes, Borges. Relações étnico-raciais e educação no Brasil - Belo Horizonte :Mazza Edições, 2011.

FREIRE, Paulo. Pedagogia da autonomia: saberes necessários apratica educativa. 58 ed. - Rio de janeiro/ São Paulo: Paz e Terra, 2019. 
GOMES, Flávio dos Santos. De olho em Zumbi dos Palmares:historias símbolos e memória social - 1ํed. - São Paulo: claro enigma, 2011.

MATTOS, Regina Augusto de. Historia e cultura afro-brasileira. 2 ed. $1^{\underline{a}}$ reimpressão. - São Paulo : Contexto, 2012.

MUNANGA, Kabengele. Origens africanas do Brasil contemporâneo:historias, linguagens, cultura e civilização. 3 ed. - São Paulo: Gaudí Editorial, 2012

MUNANGA, Kabengele. Gomes, Nilma Lino. O negro no Brasil de hoje - São Paulo : Global, 2006.

SOUZA, Laura olivieri Carneiro de. Quilombos: identidade e história1 ed. Rio de Janeiro: Nova Fronteira, 2012.

3. Pessoas que procuravam escravos fugitivos.

Enviado: Novembro, 2019.

Aprovado: Março, 2020. 